\title{
Interfaces Entre Demanda e Humanização: o Discurso dos Profissionais
}

\author{
Junges, José Roque; Oliveira, Márcia Regina de \\ Universidade do Vale do Rio dos Sinos (Unisinos) — roquejunges@hotmail.com
}

A humanização dos serviços da atenção primária à saúde depende, em grande parte, da

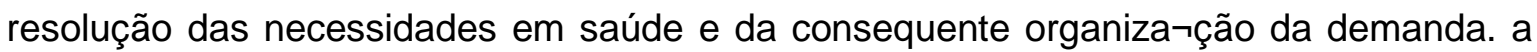
configuração da demanda depende de uma construção social que, deixada em sua expressão espontânea, tem fortes implicações sobre a humanização dos serviços. por isso é importante conhecer o discurso dos profissionais sobre a demanda. OBJETIVO: o artigo objetiva conhe-cer as implicações da demanda sobre a humanização das práticas de atenção primária. METODOLOGIA: Trata-se de uma pesquisa exploratória com abordaᄀgem qualitativa. o universo empírico da pesquisa foi composto por 10 trabalhadores de uma Unidade Básica de Saúde da cidade São Leopoldo (RS): 1 gestora, 1 médica, 1 dentista, 2 enfermeiros, 3 técnicos em enfermagem, 1 atendente da portaria $\mathrm{e}$ 1 encarregado do almoxarifado. a coleta de dados aconteceu em 4 reuniões de discussão focal sobre temas como política de humanização, direito à saúde, integralidade, acolhimento, subjetividade em saúde, processos de trabalho. As discussões foram gravadas e transcritas. Os dados foram trabalhados pela análise do discurso. RESULTADOS: como reᄀsultados, apareceram três repertórios linguísticos ligados à demanda: 1) compreensão das necessidades em saúde; 2) entendimento do acolhimento como tria ᄀgem e aplicação de protocolo; 3) influência do modelo biomédico na organização dos serviços. DISCUSSÃO: a excessiva demanda e a falta de resolubilidade estão ligadas a uma compreensão das necessidades de saúde como o simples acesso à tecnologia, e do acolhimento apenas como triagem de sintomas. Os profissionais da enfermagem reportam como uma causa da ex $\neg$ cessiva demanda o fato dos usuários querer serem atendidos pelo médico, o que pode ser explicado pela cultura da atenção criada pelo mo $\neg$ delo biomédico no qual eles próprios se encontram quando entendem as necessidades e $\mathrm{o}$ acolhimento na perspectiva biomédica.

Palavras-chave: Humanização; Atenção Primária à Saúde; Demanda; Necessidades em saúde; Acolhimento; Profissionais.

Junges, José Roque; Oliveira, Márcia Regina de. Interfaces Entre Demanda e Humanização: o Discurso dos Profissionais. In: Anais do Congresso Internacional de Humanidades \& Humanização em Saúde [= Blucher Medical Proceedings, num.2, vol.1]. São Paulo: Editora Blucher, 2014. ISSN 2357-7282 DOI 10.5151/medpro-cihhs-10270 